\title{
Growth performance of Savanna brown goats fed enzyme treated sawdust diets under intensive managed system
}

Ogbiko, A., Tsado, D. N., Alabi, O. J. and Adama, T. Z.

Department of Animal Production, School of Agriculture and Agricultural Technology,

Federal University of Technology, P. M. B 65, Minna, Niger State, Nigeria.

Corresponding author: alabioj@gmail.com: 09030083008

\begin{abstract}
This study was conducted to determine the growth performance and correlation matrix of Savanna Brown goats fed enzyme treated sawdust diets managed intensively. A total of thirty (30) goats weighting between 5.2 and $5.3 \mathrm{~kg}$ were arranged in a completely randomized design. The animals were divided into five dietary Treatments (T) groups with three replications. Treatment one (1) comprises of animals fed $0 \%$ enzyme treated sawdust while Treatment 2 (T2), Treatment 3 (T3), Treatment 4 (T4) and Treatment 5 (T5) comprises of animals fed 10, 20, 30 and 40\% enzyme treated sawdust diets, respectively. Data on growth performance parameters, body linear measurement (height at wither, body length, chest girth, hind leg length, fore leg length, facial length) were measured. Growth performance data were analyzed using one way analysis of variance. The results of growth performance reveled that animals fed $20 \%$ and $40 \%$ had significantly highest value, these trend was observed in total weight gain $(T 3=4900 \mathrm{~g}$ and $T 5=4833 \mathrm{~g})$, average weight gain $(T 3=50 \mathrm{~g}$ and $T 5=49.32 \mathrm{~g})$, totalfed intake $(T 3=2956.20$ and $T 5=2709.30 \mathrm{~g})$ and average feed intake $(T 3=211.16 \mathrm{~g}$ and $T 5=193.52 \mathrm{~g})$. However, in feed conversion ration no significant difference was observed across all the treatment groups as the value range between 3.87 in animals fed $40 \%$ to 7.12 in those fed $10 \%$ enzyme treated sawdust diet. A positive and significant correlation was observed between body weight and chest girth with highest correlations in animals fed $20 \%$ enzyme treated sawdust (0.97). It was therefore concluded that enzyme treated sawdust can be used in the diets of Savanna Brown goats up to $40 \%$ replacement for maize offal for optimum performance
\end{abstract}

Keywords: sawdust diets, savanna brown goat, correlation matrix, growth performance

\section{Introduction}

Small ruminants, particularly, goats have been noted to play important role in animal protein production since they have the ability to convert forages, agricultural and industrial by products to useful body products (Banerjee et al., 2009). However, in Africa, they are faced with poor nutrition, particularly, during the dry season (Ravhuhali et al., 2011). This is because during these periods, animals suffer phases of starvation as an effect of scarcity and decrease in the nutrient contents of forages (Nwaigwe et al., 2007). In times like these, most accessible ruminant feedstuffs turn out to be fibrous, with little nutrient and dry matter digestibility, thus, leading to poor livestock production (Mubi et al., 2008; Asaolu et al., 2011). Processing some of these products might be a way of meeting up the nutrient gap during the dry season. Sawdust is the main by-product of wood processing in sawmills. It is, generally regarded as a waste, unless reprocessed into particle board, burnt in sawdust burner or used to make heat for other milling operations (Eze et al., 2011). Sawdust if not properly handled may collect in piles and add harmful leachates into water systems and block the water ways, thereby, creating an environmental hazard (Eze et al., 2011). Sawdust treatment may assist in degrading lignin, cellulose and hemicellulose to usable materials that can be utilized by 


\section{Growth performance of Savanna brown goats fed enzyme treated sawdust diets}

ruminant animal (Belewu, 2006 and Akinfemi et al., 2013). Feed enzymes have been used to improve a wide range of diets containing legumes, grasses, haylage, straw and other feedstuffs (Beauchemin et al., 2003). The effect on enzyme treated sawdust is not fully understood. This experiment was therefore aim at determining the effect of enzyme degraded sawdust-based diets on the growth performance and correlation matrix of Savanna Brown goats under intensive management system.

\section{Materials and methods Location of the study}

The study was conducted at the Teaching and Research Farm, and Laboratory of the Department of Animal Production, Federal University of Technology Minna. Minna is located in the Southern Guinea Savanna zone on latitude and longitude $9^{0} 37$ North and $6^{0} 32$ East, respectively, it has temperature ranges of 38 to 40 degree centigrade. Rainfall in Minna is between 1,200 and $300 \mathrm{~mm}$. It an altitude of 1,475m above sea level with two (2) seasons of wet from April to October and dry from November to March (Climatemp, 2019).

\section{Sources of sawdust and enzymes}

Sawdust was obtained from saw mills located around Minna. It was sundried for 24 hours. The sawdust was sorted to remove unwanted particles before use. The enzymes (xylanase and cellulase) were prepared at the Department of Biochemistry laboratory of Federal University of Technology (Bosso campus), Minna, Niger State.

\section{Experimental animals, management and designs}

A total of thirty (30) Savanna Brown goats with an average weight of $5.26 \mathrm{~kg}$ were sourced from the University farm. Before the commencement of the study, the pens were thoroughly washed and cleaned using disinfectant (Izol) and allowed to dry for one week. Ecto-parasites were checked using Ivermectin and pour on, while animals were dewormed internally using albendazole.

The goats were kept intensively where they were offered concentrate feed (300 g/goat) in the morning while in the evening roughage were offered (250 g/goat) as supplement. Feed were given to goats daily. The diets were offered at $4 \%$ body weight, fresh water was provided ad libitum. This experiment lasted for four months.

\section{Data collection \\ Growth performance}

Live weight and body linear measurements of the goat were taken at the commencement of the experiment. Weekly mean live weights, feed intakes and liner body measurements were taken until termination of the experiment. Daily mean live weights and feed intakes were calculated from the weekly measurements. Feed conversion ratios were also calculated. Daily feed intake was measured by subtracting the leftover feed from the total feed given to the animals per head per day. Feed conversion ratio was calculated from feed consumed and weight gain for each replicate by dividing the weekly feed consumption value by the respective weight gains of the replicates for the week. This was determined from the weekly weight gained and feed consumption of each treatment as described by Anaeto et al. (2009) using the following formula:

$$
\text { F.C.R }=\frac{\text { Average weekly feed intake }(\mathrm{g})}{\text { Average weekly weight gain }(\mathrm{g})}
$$

\section{Body weight and linear measurements}

Body weight $(\mathrm{kg})$ was taken using weighing scale. All linear measurements were carried out according to the procedure described by Adewumi (2014) using a measuring tape. Body length (BL) was measured as the distance from the external occipital protuberance to the base of the tail. Heightat-withers (HAW) was measured as the distance from the surface of a plat form to 
the withers or measured on dorsal midline of the highest point on the withers. Chest girth (HG) was measured as body circumference just behind the fore legs. Facial length was measured as the distance from the centre of the poll (horn) to the tip of the upper lips. Hind limbs length was measured as the distance from hoof to the top of the pin bone. Fore limb length was measured as the distance from the hoof to the crest of the shoulder.

\section{Data analysis}

All data collected were subjected to analysis of variance (ANOVA) using the computer software package SPSS 17.0 (SPSS, 2008). Difference among means was separated using Duncan's multiple range test.

Table 1: Composition of experimental diets (\%)

\begin{tabular}{llllll}
\hline & $\mathrm{T}_{1}$ & $\mathrm{~T}_{2}$ & $\mathrm{~T}_{3}$ & $\mathrm{~T}_{4}$ & $\mathrm{~T}_{5}$ \\
Ingredients & $0 \% \mathrm{SDM}$ & $10 \% \mathrm{SDM}$ & $20 \% \mathrm{SDM}$ & $30 \% \mathrm{SDM}$ & $40 \% \mathrm{SDM}$ \\
\hline Maize & 29.09 & 29.09 & 29.09 & 29.09 & 29.09 \\
Maize offal & 58.18 & 52.36 & 46.54 & 40.73 & 34.91 \\
$\mathrm{SDM}$ & 0.00 & 5.82 & 11.64 & 17.45 & 23.27 \\
GNC & 8.73 & 8.73 & 8.73 & 8.73 & 8.73 \\
Bone meal & 3.00 & 3.00 & 3.00 & 3.00 & 3.00 \\
Salt & 0.50 & 0.50 & 0.50 & 0.50 & 0.50 \\
Premix & 0.50 & 0.50 & 0.50 & 0.50 & 0.50 \\
Total & 100 & 100 & 100 & 100 & 100 \\
Calculated analysis & & & & & \\
Energy (Kcal) & 2819.19 & 2704.77 & 2590.35 & 2476.11 & 2361.69 \\
Crude protein & 13.44 & 13.30 & 13.16 & 13.02 & 12.87 \\
Crude fibre & 7.23 & 9.53 & 12.14 & 14.13 & 16.43 \\
Ether extract & 2.95 & 2.97 & 2.98 & 3.00 & 2.30 \\
Lysine & 0.23 & 0.23 & 0.23 & 0.23 & 0.23 \\
Methionine & 0.10 & 0.10 & 0.10 & 0.10 & 0.10 \\
Calcium & 1.14 & 1.14 & 1.14 & 1.14 & 1.14 \\
Phosphorus & 0.58 & 0.58 & 0.58 & 0.58 & 0.58 \\
\hline Results and & & & $b y$ &
\end{tabular}

\section{Results and discussions}

Proximate composition of raw sawdust and enzyme-treated sawdust

The results of the proximate composition of raw and enzyme treated sawdust are presented in Table 2. The results indicate that crude protein content (9.45) and ash content (4.50) of enzyme-treated sawdust was higher than that of raw sawdust. However dry matter (71.60), crude fibre (50.00) and ether extract (5.65) of the enzyme-treated sawdust were lower than the raw sawdust. The value of crude protein (9.45) of enzyme treated sawdust obtained in this work is slightly higher to the value (8.80) obtained by Oke and Oke (2007). This implied that enzyme treated sawdust may be used as a source of protein in the diets of animals. The crude protein observed in this experiment is also higher than the crude protein value (2.7) obtained by Hossain et al. (2012) who worked on estimated nutritive value of sawdust. The crude fibre and protein in the enzymetreated sawdust is similar to those of maize offal and, thus, it can be used to replace maize offal in the diets of animals.

Proximate composition of experimental diets fed to savanna brown goats

Proximate composition of experimental diets is presented in Table 3 . The dry matter was within the range of 96.00 (T5) and 94.20 (T2), the crude protein is within the range of 15.23 (T3) and 14.23 (T1). The crude fiber result content highest in T5 (20.00) and lowest in T1 (6.00). The nitrogen free extract and energy value reduces as the sawdust inclusion increases crude protein content of these diet ranges between 13 and $15 \%$ which is slightly higher than the $12 \%$ recommended value for goats (NRC, 2007). 
Table 2. Proximate composition of raw sawdust and enzyme-treated sawdust

\begin{tabular}{lcc}
\hline Parameter (\%) & Raw sawdust & Enzyme-treated sawdust \\
\hline Dry Matter & 92.60 & 71.60 \\
Crude Protein & 2.62 & 9.45 \\
Crude Fiber & 61.50 & 50.00 \\
Ether Extract & 16.70 & 2.00 \\
Ash & 4.02 & 4.50 \\
Nitrogen Free Extract & 16.70 & 5.65 \\
ME (Kcal/kg) & 1471.20 & 784.00 \\
\hline
\end{tabular}

Table 3. Proximate Composition of experimental diets fed to Savanna Brown goats

\begin{tabular}{llllll}
\hline PARAMETERS & $0 \%$ SDM & $10 \%$ SDM & $20 \%$ SDM & $30 \%$ SDM & $40 \%$ SDM \\
\hline Dry matter & 95.60 & 94.20 & 95.60 & 94.60 & 96.00 \\
Crude protein & 14.23 & 14.53 & 15.23 & 15.05 & 14.70 \\
Crude fibre & 6.00 & 7.50 & 16.81 & 15.00 & 20.00 \\
Ash & 10.50 & 10.45 & 10.26 & 11.46 & 11.28 \\
Ether extract & 3.84 & 4.28 & 4.46 & 3.98 & 4.71 \\
NFE & 61.03 & 57.44 & 48.84 & 48.11 & 45.31 \\
Energy kcal $/ \mathrm{kg}$ & 3356.00 & 3264.00 & 2964.20 & 2884.60 & 2824.30
\end{tabular}

\section{Keys}

$0 \% \mathrm{SDM}=0 \%$ Inclusion of enzyme -treated sawdust; $10 \% \mathrm{SDM}=10 \%$ Inclusion of enzyme -treated sawdust; 20 $\% \mathrm{SDM}=20 \%$ Inclusion of enzyme-treated sawdust; $30 \% \mathrm{SDM}=30 \%$ Inclusion of enzyme-treated sawdust; $40 \%$ $\mathrm{SDM}=40 \%$ Inclusion of enzyme-treated sawdust; NFE = Nitrogen Free Extract

Growth performance of savanna brown goats fed enzyme treated sawdust diet as replacement for maize offer managed under intensive system

Table 4 shows the results of growth performance of savanna brown goats fed diets containing varying levels of enzyme treated sawdust diets managed intensively. The results indicated that there was no significant $(\mathrm{p}>0.05)$ difference in the initial body weight of animals among the treatment groups. There was, however, significant $(p<0.05)$ differences in the final weight (total weight gain daily weight gain. Animals fed $20(10250.00 \mathrm{~g})$ and $40 \%$ (10083.00 g) enzyme treated sawdust meal had significantly higher values as compared to animals fed $0(8050 \mathrm{~g})$ and 30 $\%(7766.70 \mathrm{~g})$ but statistically similar to those fed $10 \%$.The total feed intake and average feed intake for animals fed 20 and $40 \%$ are statistically higher but can be compared statistically to animals fed 0 and $10 \%$, while, animals fed $30 \%$ enzyme treated sawdust diets had significantly lowest value than the other treatments. There was no significant $(p>0.05)$ difference in feed conversion ratio of experimental animals across all the treatment groups. The significant $(\mathrm{p}<0.05)$ difference observed in the final weight, total weight gain and average daily weight gain in favour of goats fed $20 \%$ and $40 \%$ could mean that up to $40 \%$ inclusion of enzyme treated sawdust in the diets of Savanna Brown goats is favourable. This agrees with the submission of Titi (2004) who reported significant difference in final body weight and daily weight gain when cellulase enzyme treated forage was given to Awassi lambs. Daniel et al. (2016) also reported significant difference in total body gain and average daily gain when they worked on effect of exogenous enzyme and application method on nutrient intake, digestibility and growth performance of Pelibuey lamb. The significant difference observed in total feed intake and average feed intake in this work disagrees with the work of Yashim et al. (2016) who reported 


\section{Ogbiko, Tsado, Alabi and Adama}

no significant difference in total feed intake and average daily weight gain of Red Sokoto bucks fed graded levels of dried sweet orange peel meal. However, the result is in line with the report of Ibrahim and Olofin (2013) who observed significant differences in feed intake and average daily weight gain of goats fed treated sawdust. Moniruzzaman et al. (2002) recorded significant variations in in feed intake of Black Bengel goats in stall-fed goats, highest value in average live weight gain compared to those tethered, restricted grazing and grazing goats. Carlo et al. (2014) noted that with an increase in feed intake there was a corresponding increase in body weight gain.

Table 4: Growth performance of savanna brown goats fed enzyme treated sawdust diet as replacement for maize offal managed under intensive system

\begin{tabular}{|c|c|c|c|c|c|c|c|}
\hline Parameters (g) & $0 \% \mathrm{SDM}$ & $\begin{array}{l}10 \% \\
\text { SDM }\end{array}$ & $20 \% \mathrm{SDM}$ & $\begin{array}{l}30 \% \\
\text { SDM }\end{array}$ & $40 \% \mathrm{SDM}$ & SEM & $\begin{array}{l}p- \\
\text { value }\end{array}$ \\
\hline Initial weight & 5100.00 & 5283.30 & 5350.00 & 5316.70 & 5250.00 & 30.17 & 0.07 \\
\hline Final weight & $8050.00^{\mathrm{b}}$ & $8833.30^{\mathrm{ab}}$ & $10250.00^{\mathrm{a}}$ & $7766.70^{\mathrm{b}}$ & $10083.00^{\mathrm{a}}$ & 301.05 & 0.01 \\
\hline Total weight gain & $2950.00^{b}$ & $3550.00^{\mathrm{ab}}$ & $4900.00^{\mathrm{a}}$ & $2450.00^{\mathrm{b}}$ & $4833.30^{\mathrm{a}}$ & 297.94 & 0.02 \\
\hline Average daily weight gain & $30.10^{\mathrm{b}}$ & $36.22^{\mathrm{ab}}$ & $50.00^{\mathrm{a}}$ & $25.00^{\mathrm{b}}$ & $49.32^{\mathrm{a}}$ & 3.04 & 0.02 \\
\hline Total feed intake & $2125.50^{\mathrm{ab}}$ & $2584.00^{\mathrm{ab}}$ & $2956.20^{\mathrm{a}}$ & $1751.40^{\mathrm{b}}$ & $2709.30^{\mathrm{a}}$ & 142.57 & 0.04 \\
\hline Average feed intake & $151.82^{\mathrm{ab}}$ & $184.58^{\mathrm{ab}}$ & $211.16^{\mathrm{a}}$ & $125.10^{\mathrm{b}}$ & $193.52^{\mathrm{a}}$ & 10.18 & 0.04 \\
\hline Feed conversion ratio & 5.89 & 7.12 & 4.52 & 5.00 & 3.87 & 0.58 & 0.46 \\
\hline
\end{tabular}

$\mathrm{ab}=$ Means with different superscript are significantly $(\mathrm{P}<0.05)$ different

$\%$ SDM $0 \%$ Inclusion of enzyme -treated sawdust; $10 \%$ SDM $=10 \%$ Inclusion of enzyme -treated sawdust; $20 \%$

$\mathrm{SDM}=20 \%$ Inclusion of enzyme -treated sawdust; $30 \% \mathrm{SDM}=30 \%$ Inclusion of enzyme -treated sawdust; $40 \%$

$\mathrm{SDM}=40 \%$ Inclusion of enzyme-treated sawdust; SEM = Standard error of Mean

Correlation matrix between body weight and body linear measurements of savanna brown goats fed diets containing enzyme treated sawdust diets and managed intensively

The correlation matrix between body weight and body linear measurements of Savanna Brown goats fed diets containing enzyme treated sawdust diets and managed intensively are presented in Table 5. There is high correlation between body weight and body linear measurement among the treatment groups except for the control and animal fed $30 \%$ enzyme treated sawdust diets that have negative correlation. However, the positive and significant correlations between body weight and chest girth observed in all treatment groups with the highest correlated in animals fed $20 \%$ enzyme treated sawdust (0.97) indicates that chest girth can be used to predict live weight of animals and this agrees with most report of previous study like Mudala et al. (2016), Atta et al. (2004) among others.

Table 5: Correlation matrix between body weight and body linear measurements of Savanna Brown goats fed diets containing enzyme treated sawdust diets and managed intensively

\begin{tabular}{llllll}
\hline & $0 \%$ & $10 \% \mathrm{SDM}$ & $20 \%$ & $30 \%$ & $40 \%$ SDM \\
PARAMETERS & SDM & & SDM & SDM & \\
\hline Body weight and height at withers & -0.20 & $0.65^{*}$ & $0.87^{* *}$ & -0.53 & $0.91^{* *}$ \\
Body weight and body length & -0.22 & $0.60^{*}$ & $0.84^{* *}$ & -0.31 & $0.92^{* *}$ \\
Body weight and chest girth & $0.78^{* *}$ & $0.86^{* *}$ & $0.97^{* *}$ & $0.62^{*}$ & $0.96^{* *}$ \\
Body weight and hind leg length & -0.08 & $0.64^{*}$ & $0.87^{* *}$ & $-0.55^{*}$ & $0.90^{* *}$ \\
Body weight and fore leg length & -0.13 & $0.63^{*}$ & $0.85^{* *}$ & -0.48 & $0.93^{* *}$ \\
Body weight and facial length & -0.01 & $0.69^{* *}$ & $0.90^{* *}$ & -0.31 & $0.93^{* *}$ \\
\hline
\end{tabular}

$* *$ Correlation is significant at 0.01 level (2-tailed) * Correlation is significant at 0.05 level (2-tailed) Keys; $0 \% \mathrm{SDM}=0 \%$ Inclusion of enzyme-treated sawdust; $10 \% \mathrm{SDM}=10 \%$ Inclusion of enzyme-treated sawdust; $20 \% \mathrm{SDM}=20 \%$ Inclusion of enzyme -treated sawdust; $30 \% \mathrm{SDM}=30 \%$ Inclusion of enzyme -treated sawdust; $40 \% \mathrm{SDM}=40 \%$ Inclusion of enzyme-treated sawdust 
Growth performance of Savanna brown goats fed enzyme treated sawdust diets

Conclusions and recommendation

Based on the results obtained from this study, it can therefore be concluded that the replacement of enzyme treated sawdust in Savanna Brown goats' diets up to $40 \%$ positively influenced the measurement of body weight and other body linear measurement. Goats fed $40 \%$ inclusion of enzyme treated sawdust had their chest girth most correlated to body weight. Thus, chest girth can be used to predict body weight of Savanna Brown goats. Therefore, enzyme treated sawdust diets up to $40 \%$ is recommended for Savanna Brown goats diets for better performance.

\section{References}

Adewumi, O. O. 2014. Genetic and nongenetic factors affecting the performance of West African Dwarf (WAD), Yankasa (YAN) and WAD X YAN lambs in the tropics. Nigerian Journal of Animal Production 41(2): 44-52.

Akinfemi, A. and Ladipo, M. K. 2013. Bioconversion of Daniellia oliveri Tree Sawdust into Ruminant $\quad F$ e e d.$P A T$ (1):105-113 ISSN: 0794-521.3 www.patnsukjournal.net/currentis sue

Anaeto, M., Tayo, G. O., Chioma, G. O., Ajao, A. O. and Peters, T. A. 2009. Health and nutrition practices among smallholder sheep and goat farmers in Ogun State. Livestock Research for Rural Development, 21 (11).

Asaolu, V. O., Binuomote, R. T., Akinlade, J. A., Oyelami, O. S. and Kolapo, K. O. 2011. Utilization of Moringa oleifera fodder combinations with Leucaena leucocephala and Gliricidia sepium fodders by West African dwarf goats. International Journal of Agricultural Research
6: 607-619.

Attah, S., Okubanjo, A. O., Omojola, A. B. and Adesehinwa, A. O. K. 2004. Body and carcass linear measurements of goats slaughtered at different weight. Livestock research for rural development 16 (8)

Beauchemin, K. A., Colombatto, D., Margavi, P. and Yang, W. Z. 2003. Use of exogenous fibrolytic enzymes to improve feed utilization by ruminants. Journal of Animal Science 81:37-47

Belewu, M. A. 2006. Conversion of masonia tree sawdust and cotton plant by-productinto feed by white-rot fungus (Pleurotus sajor caju). African Journal of Biotechnology 5(6):503-504.

Benerjee, R., Mandal, P. K., Bose, S., Benerjee, M. and Manna, B. 2009. Quality evaluation of meat, skin and wool from Garole sheep a promising breed from India. Asian Journal of animal science 3: 39-46

Carlo, A. T. M., Ariosvaldo N. de M., Roberto, G. C., Francisco F. R. de C., Marcos J. de A., and Jacira N. da C. T. 2014. Performance and carcass traits of Moxotó growing goats supplemented on native pasture under semiarid conditions R. Bras. Zootec., 43(3):151-159.

Climatetemp. Minna climate information 2019. Retrieved on $28^{\text {th }}$ May, 2009, from http://www.climatetemp.info /nigeria/minna.htm

Daniel, L., Javier, H., Rolando, R., Fernando, S., Nicolás, L., AbdelFattah Z. M. S., Juan, C. M., José F. V. and Salomón, R. 2016. Effects of exogenous enzymes and application method on nutrient intake, digestibility and growth performance of Pelibuey lambs. 
Springerplus 5(1): 1399.

Eze, V. C., Uzoaru, N. and AgwungFobellah, D. 2011. Isolation and $\mathrm{c} h$ a r a c t e r i z a t i o $\mathrm{n}$ of microorganisms involved in degradation of sawdust waste in River State, Nigeria. Journal of science and technology 1(4): 4448.

Hossain, M. E., Rahman, M. J.and Islam, K. M. F. 2012. Nutritive value of sawdust.Online Journal Animal Feed Research 2(3): 288-291.

Ibrahim, Y. El-ladan and Olofin, E. A. 2013. Evaluation of variously treated sawdust as partreplacement for molasses-treated wheat offal in goat (Capra prisca) ration.International Journal of Pure and Applied Science and Technology 19(1): 65-69

Moniruzzaman, M., Hashem, M. A., Akhter, S. and Hossain, M. M. 2002. Effect of feeding systems on feed intake, eating behavior, growth, reproductive performance and parasitic infestation of Black Bengel goat. Asian-Australian Journal of Animal science 15(10): 1453-1457

Mubi, A. A., Kibon, A. and Mohammed, I. D. 2008. Utilization of alkali treated sorghum stover supplemented with poultry litter for growing heifers in the North East Region of Nigeria. Asian Journal Animal Veterinary Advances 3: 183-186.

National Research Council 2007. Nutrient requirement for animals. National Academy Press, Washington DC.

Nwaigwe, C. O., Kamalu, T. N., Nwankwo, C. U. and Nwaigwe, A. N. 2007. Studies on the nutritional characteristics and palatability of Gmelina aborea,
Costus afer, Alchornea cordifolia and maize silages. Proceedings of the 44th Annual Conference of Nigeria Veterinary Medical Association, October 22-26, 2007, Effurun, Delta State, Nigeria

Oke, D. B. and Oke, M. O. 2007. Effect of feeding graded levels of sawdust obtained from Daniellia ogea tree on the performance and carcass characteristics of broiler chickens Research Journal of Poultry Science 1(1): 12-15

Ravhuhali, K. E., Ng'ambi, J. W., Norris, D. and Ayodele, V. I. 2011. The feeding value of four cowpea hay cultivars and effect of their supplementation on intake and digestibility of buffalo grass hay fed to pedi goats. Asian Journalof Animal Veterinary Advances 6: 909-922.

SPSS INC 2008. Statistical Package for Social Sciences (SPSS) 17.0 for windows, SPSS inc. USA.

Titi, H. H. 2004. Response of Awassi Lambs to EnzymaticTreatment Fed Two Different Forages: 1 . Digestibility and Growth Performance. Dirasat, Agricultural Sciences 31:302-310.

Yashim, S. M., Adekola, S. T., Abdu, S. B., Gadzama, I. U. and Hassan, M. R. 2016. Feed intake, growth performance and nutrient digestibility in growing Red Sokoto bucks fed diets containing graded levels of dried sweet orange peel meal. Animal Research international 13 (1): 2328-2337.

Received: $7^{\text {th }}$ September, 2019

Accepted: $26^{\text {th }}$ January, 2020 